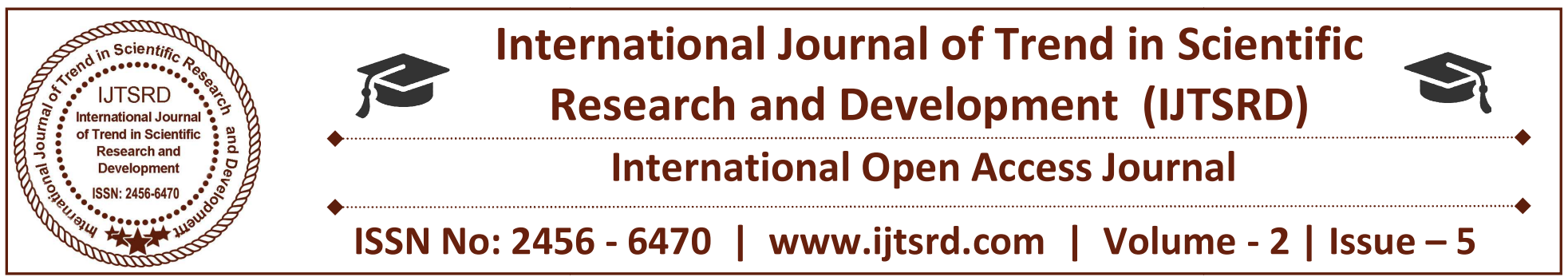

\title{
Appointment of Chief Justice of India, Powers and Accountability with Analysis of Cases : An Overview
}

\author{
Bhanupriya Singh Markam \\ B.A., LL.B (Hons), Indore Institute of Law \\ Indore, Madhya Pradesh, India
}

\begin{abstract}
This research particularly focuses on the power and accountability of Chief justice of India, and the analysis of accomplishment of balancing the slope of Power and Accountability and the justification of centralization of power on the office of Chief Justice of India while discussing the appointment and role played by the CJI, the primary focus of the research is to know whether there is need of new reforms in terms of accountability with regards to increase in power of the post of CJI or the current system can provide the fair and sustainable result and the of impeachment process
\end{abstract}

\section{INTRODUCTION}

The Indian Constitution is the lengthiest in the whole world and Indian democracy is the largest democracy in the world with the having to resolute to secure "Liberty", "Equity", "Fraternity" and "Justice" to its citizens by constituting India into a Sovereign Secular Socialist Democratic Republic, and by being democratic its government is for the people, of the people and by the people ${ }^{1}$ Therefore the government has a duty to secure to all its citizen Liberty, Fraternity, Equity and Justice by constituting India into an Idyllic Sovereign Socialist Secular Democratic Republic.

Being the democratic government; Legislature, Executive and Judiciary, it is their responsibility to execute and interpret the laws for the welfare of the people according to their aspirations. If they fail to do so they have to be answerable to the public or the people of the country.

${ }^{1}$ Abraham Lincoln, Gettysburg Address, November 19th 1863

There is a separation of power between Legislature, Executive and Judiciary and Judiciary plays a crucial role in upholding the constitutional rights of the people and plays as the protector of the rights of the people while ensures that the Legislature and Executive are working in Therefore the Judiciary, especially, the High Court and the Supreme Court are empowered by the constitution with some of the most significant powers protecting the rights of the people, guarding the Constitution, interpreting the laws in the public interest and thereby exercising its jurisdiction. With the empowerment comes the "Independence of Judiciary" to uphold the responsibility The concept of the "Independence of Judiciary" is of common law origin originated in UK and thus it has not been properly codified, as to, from whom the judiciary is independent, what is the extent of their independence and at what point does this independence end. Therefore, as a consequence the present day judiciary has been superfluously empowered behind undefined curtains under the principle of the "Independence of Judiciary". The ultimate consequence can simply be described by a simple saying that "Power corrupts man and absolute power corrupts absolutely", In the name of "Independence of Judiciary" the Judiciary has been empowered and thus the horizon or jurisdiction has also been expanded The expanding prospects of the powers and authorities of the Higher Judiciary has also led to the obvious consequence of judges pandering to corrupt practices, which is evident from several recent cases. The cases involving Justice Soumitra Sen of the Calcutta High Court, Chief Justice P.D. Dinakaran of the Sikkim High

2 John Emerich Edward Dalberg Acton, 1stBaron Acton, Letter to Bishop Creighton, April 5, 1887 
Court and Justice Nirmal Yadav of the Uttarakhand High Court are all at various stages. The only reason for all this is the delegation of extraneous powers in the hands of the judges in the name of independence and lack of accountability. As Montesquieu says that, "Constant experience has shown us that every man invested with power is apt to abuse it, and to carry his authority until he is confronted with limits ${ }^{3}$. Today the Higher Judiciary having been enormously empowered with authority and extended jurisdiction has started abusing its power, and will continue abusing it until it's confronted with limits and is subjected to accountability.

The present condition is that in a system of governance built on the principles of Separation of Powers, Rule of Law and Checks and Balance the Higher Judiciary is still unchecked and there is no effective system, authority or institution to judge the judges for their malfunction and misbehaviour, if there's, then the system is so ineffective that in last 64 years since the adoption of our Constitution there have been no impeachment or disciplinary actions against even a single one.

In a Democratic country where the protection of rights , interpretation of law and the organ which is entrusted with the power of serving " justice for all" must be subjected to accountability.

\section{(G) JUDICIAL ACCOUNTABILITY BILL APPROVED}

The Judicial Standards and Accountability Bill will set judicial standards and make judges accountable for their lapses. It will also mandate that judges of the high court's and the Supreme Court declare their assets and liabilities, including those of their spouses and dependants. The Union Cabinet has approved the draft Judicial Standards and Accountability Bill, 2010 that provides for setting up a five-member oversight committee to deal with complaints against members of the higher judiciary. Official sources said judges would also be required to declare their assets and file an annual return of assets and liabilities. All these details will be put up on the websites of the Supreme Court and high courts. It will further require judges not to have close ties with any member of the Bar, especially those who practise in the same court. "The enactment of the Bill will address the growing concerns regarding the need to ensure greater

\footnotetext{
${ }^{3}$ Montesquieu: The Spirit of Laws: Book 11
}

accountability of the higher judiciary by bringing in more transparency, and will further strengthen the credibility and independence of the judiciary," Information and Broadcasting Minister Ambika Soni told reporters after a meeting of the Union Cabinet. The proposed oversight committee will be headed by a former chief justice of India and include the attorney general, a Supreme Court judge, a chief justice of a high court and an eminent person nominated by the President.

\section{OVERSIGHT COMMITTEE}

The Bill to replace the Judges Inquiry Act retains its basic features, contemplates setting up of a national oversight committee, to be headed by a former Chief Justice of India, with which the public can lodge complaints against erring judges, including the Chief Justice of India and the Chief Justices of the High Courts. At present, there is no legal mechanism for dealing with complaints against judges, who are governed by 'Restatement of Values of Judicial Life,' adopted by the judiciary as a code of conduct without any statutory sanction.

The five-member committee to be appointed by the President will have a serving judge of the Supreme Court and a serving High Court judge, both nominated by the Chief Justice of India; the AttorneyGeneral; and an eminent person nominated by the President.

\section{SCRUTINY PANELS}

On receiving a complaint, the committee will forward it to a system of scrutiny panels. In the case of a complaint against a Supreme Court judge, the scrutiny panel will consist of a former Chief Justice of India and two sitting Supreme Court judges, and in the case of a complaint against a High Court judge, the panel will have a former Chief Justice of the High Court and two of its sitting judges. The members of the Supreme Court panel will be nominated by the Chief Justice of India, and that of the High Court panels by the Chief Justice of the High Court concerned. The scrutiny panels will have the powers of a civil court. For instance, they can call for witnesses and evidence. They will be required to give their report within three months to the oversight committee. In the case of a complaint against a Chief Justice, the oversight committee itself will conduct the scrutiny. On receiving the report from the scrutiny panels, the oversight committee will set up a committee to further investigate the case. Like the scrutiny panels, the 
investigation committee will have the powers of a civil court; it will have the power to frame definite charges. If the charges are not proved, the investigation committee can dismiss the case. Otherwise, it will give a report to the oversight committee, which can issue an advisory or warning or recommend minor punishment if the charges are not too serious. If the charges are serious, the committee can request the judge concerned to resign. If the judge does not do so, the oversight committee will forward the case to the President with an advisory for his removal. The Bill mandates that judges should not have close association with individual members of the Bar and not allow any member of their immediate family to appear before them in courts. Judges should not contest any election to any office of club, society or other association, except those associated with the law or any court. Further, they should not have any bias in judicial work or judgments on the basis of religion, race, caste, sex or place of birth.

\section{(H) CONCLUSION}

Corruption in the judiciary is hardly a new phenomenon, though it has certainly increased over the years. It is worthwhile however to examine the reasons for the sudden spate of exposures of judicial corruption. Having enjoyed enormous powers, including the power of contempt, without any accountability, the higher judiciary has over the years; tread on the toes of many persons and institutions, particularly the media. Not wanting to suffer criticism, the judiciary has used its power of contempt to stifle criticism. More than 50 editors, publishers and journalists have been issued contempt notices by the Karnataka High Court for having written stories about a judicial sex scandal, reportedly involving three judges of the High Court. Small wonder then, that the media is enjoying every bit of the juicy judicial scandals that have exploded. That there has been corruption in the judiciary for many years one reason why judges have been treated as demigods in this country is because of the power of contempt wielded by them. This is a jurisdiction in which a judge against whom an allegation has been made can himself act as the complainant, prosecutor and judge. The judge can even refuse to allow the maker of the allegation to prove its truth. The very existence of this power has been enough to silence the media and inhibit them from exposing judicial misbehavior or corruption. The amendment recently moved in Parliament to make truth a defense in a contempt action is not an adequate safeguard for the citizens and the press. As the case involving the journalists who wrote about the Karnataka sex scandal shows, though the allegation may be made bona fide and on a reasonable basis, it may not always be possible to prove its truth. This could be because the witnesses are won over or the evidence disappears for some other reason. ${ }^{4}$

\section{APPOINTMENT OF CHIEF JUSTICE OF INDIA}

The Chief Justice of India and the Judges of the Supreme Court are appointed by the President under clause (2) of Article 124 of the Constitution.

Appointment to the office of the Chief Justice of India should be of the senior most Judge of the Supreme Court considered fit to hold the office. The Union Minister of Law, Justice and Company Affairs would, at the appropriate time, seek the recommendation of the outgoing Chief Justice of India for the appointment of the next Chief Justice of India ${ }^{5}$

$>$ Whenever there is any doubt about the fitness of the senior most Judge to hold the office of the Chief Justice of India, consultation with other Judges as envisaged in Article 124 (2) of the Constitution would be made for appointment of the next Chief Justice of India.

After receipt of the recommendation of the Chief Justice of India, the Union Minister of Law, Justice and Company Affairs will put up the recommendation to the Prime Minister who will advise the President in the matter of appointment.

\section{APPOINTMENT OF ACTING CHIEF JUSTICE}

Appointment of acting Chief Justice is to be made by the President under Article 126 of the Constitution. Vacancy in the office of the Chief Justice must be filled whatever the period of vacancy. In such an eventuality, the senior most available Judge of the Supreme Court will be appointed to perform the duties of the office of the Chief Justice of India. As soon as the President has approved the appointment, the Secretary to the Government of India in the Department of Justice will inform the Chief Justice of India or in his absence the Judge concerned of the

\footnotetext{
${ }^{4}$ Judicial Accountability in India (July 20, 2018, 10.20 AM) http:/www.legalservicesindia.com/article/538/JudicialAccountability-in-India.html

${ }^{5}$ Memorandum showing the procedure for Appointment of the Chief Justice Of India and Judges of the supreme court ( July 20, 2018, 02.04 PM)

http://doj.gov.in/sites/default/files/memosc.pdf
} 
Supreme Court, and will announce the appointment and issue the necessary notification in the Gazette of India.

\section{QUALIFICATIONS}

$>$ He should be a citizen of India.

$>$ He should have been for at least five years a Judge of a High Court or of two or more such courts in succession. OR

$>\mathrm{He}$ should have been for at least ten years an Advocate of a High Court or of two or more such courts in succession. OR

$>\mathrm{He}$ should be, in the opinion of the President, a distinguished jurist.

$>$ This means that no minimum age has been prescribed for his appointment.

\section{ROLE OF CJI}

The CJI is the head of the Judiciary of India and the Supreme Court of India. It is the highest post that can be achieved by a judge in India.

He allocates cases and appoints constitutional benches to deal with important cases of law.

He also heads the administrative functions of the Supreme Court.

Whenever a vacancy is expected to arise in the office of a Judge of the Supreme Court, the Chief Justice of India will initiate proposal and forward his recommendation to the Union Minister of Law, Justice and Company Affairs to fill up the vacancy.

\section{ADMINISTRATIVE FUNCTIONS:}

$>$ He allocates matters to other judges of the SC.

$>$ He maintains the roster.

The Chief Justice is the "Master of Roster" and has the authority to allocate the cases to different Benches/Judges of the Supreme Court. It is also conceded that adherence to this principle, namely, the Chief Justice is the Master of Roster, is essentially to maintain judicial discipline and decorum. It is also stated that the Chief Justice is first among equals, meaning thereby all Judges of the Supreme Court are equal with same judicial power, with Chief Justice as the senior most Judge. At the same time, it is contended that this power is not to be used to assert any superior authority by the Chief Justice and the power is to be exercised in a manner that is fair, just and transparent. As the Master of Roster, it is also conceded that it is the Chief Justice who has to decide as to which Bench will hear a particular case. The apprehension expressed is that keeping in view the predisposition of particular Judges, the Chief Justice may assign cases to those Judges to achieve a predetermined outcome.

A roster declares what work is assigned to High Court and Supreme Court Judges. 'Master of the Roster' refers to the privilege of the Chief Justice to constitute Benches to hear cases. It is a pre-requisite that this power must be exercised in a manner is that fair, just and transparent and in keeping with the high standards of integrity desired from the office of a Chief Justice of India. ${ }^{6}$

$>$ He appoints court officials.

$>$ He also carries out other general functions relating to the SC.

$>$ Other judges of the Supreme Court are appointed by the President of India after consulting the CJI and such other judges of the Supreme Court and high courts as he deems necessary. Consultation with the CJI for this purpose is obligatory.

$>\mathrm{He}$ acts as the President of India if the offices of both the President and the Vice-President lie vacant.

\section{CURRENT CONTROVERSY OF JUSTICE DIPAK MISHRA: AN ANALYSIS \\ Background}

The impeachment notice comes a day after a Supreme Court bench, headed by Chief Justice Dipak Misra, dismissed petitions seeking an independent probe into the death of Judge B H Loya, who was hearing the Sohrabuddin Sheikh encounter case, stating the death to be natural and such petitions to be an attack on the Judiciary.

Brijgopal Harkishan Loya was an Indian judge who served in a court in the Central Bureau of Investigation (CBI). He was presiding over the Sohrabuddin Sheikh case, and allegedly died under unnatural circumstances on December 1, 2014 in Nagpur, 15 days before the next hearing when the verdict was supposed to be given.

The Sohrabuddin Sheikh Encounter case involves the death of an alleged criminal Sohrabuddin Anwarhussain Sheikh on November 26, 2005, while he was in police custody

However,

> Vice President and Rajya Sabha Chairperson M Venkaiah Naidu on April 23, 2018 rejected the

${ }^{6}$ W.P. (C) No.789 of 2018 
impeachment notice submitted by the Opposition parties against Chief Justice of India Dipak Misra. Naidu rejected the notice stating that the motion lacked substantial merit and that it was based on mere suspicion, conjecture or assumption rather than factual proof. The decision comes a day after Naidu held extensive consultations with experts to determine the legality of the motion.

In a first, seven opposition parties led by the Indian National Congress had submitted a notice to the Rajya Sabha Chairman and Vice President, M Venkaiah Naidu on April 20 for the impeachment of Chief Justice of India Dipak Misra on five grounds of 'misbehavior'.

\section{- Key Highlights}

$>$ The members of Parliament who signed the notice belong to parties including the Congress, NCP, CPI-M, CPI, SP and the BSP.

$>$ The leaders of these parties earlier met in Parliament and gave final shape to the notice for impeachment.

$>$ After the meeting, Leader of Opposition Ghulam Nabi Azad confirmed that the leaders were moving the notice for impeachment against CJI.

$>$ Two parties - Trinamool Congress and the DMK, which were initially in favour of the impeachment against the CJI, are no longer a part of it.

However, Vice President Venkaiah Naidu rejected the impeachment notice submitted by the opposition. ${ }^{7}$

This was the first-ever time that an impeachment notice was filed against a sitting CJI.

\section{IMPEACHMENT PROCEDURE}

$>$ The impeachment notice of an SC judge or CJI can be moved in either House of the Parliament. However, it should be issued by at least 50 MPs from the Rajya Sabha and 100 MPs from the Lok Sabha.

$>$ The impeachment notice has to be handed over either to the Speaker of Lok Sabha if it is from the lower house MPs or to the Chairman of Rajya Sabha if it is from the upper house MPs. The

\footnotetext{
${ }^{7}$ Rajya Sabha Chairman Venkaiah Naidu rejects impeachment notice against CJI Dipak Misra (July 21, 2018, 11.11AM) https://www.jagranjosh.com/current-affairs/opposition-submitsmotion-to-impeach-chief-justice-dipak-misra-1524289344-1
}

Chairman of the Rajya Sabha is also the Vice President of India.

$>$ Once the motion is submitted to the Speaker of Chairman, the person concerned will have to constitute a three-member committee to investigate the charges leveled against the Supreme Court judge.

$>$ The three-member committee will consist of a senior Supreme Court judge, a High Court judge and a 'distinguished jurist' who has been appointed as a Supreme Court judge by the President of India.

$>$ The three-member committee has to support the motion for it to be sent back to the House where it was introduced.

$>$ In the House, it has to be discussed and passed with a special majority — not less than two-thirds. This means, in case of a full House, at least 364 Members should have voted for the motion in the Lok Sabha, and 164 Members in the Rajya Sabha.

$>$ Once the motion is passed by the house it was introduced in, it has to be passed on to the other House where it again needs to be passed by special majority.

$>$ Once it is passed by both the Houses of Parliament, then the President can be approached to remove the Chief Justice of India.

\section{CONCLUSION}

One must realize that in countries like India the judiciary is relied upon by the citizenry to solve many of their difficulties and therefore consistent standards of accountability that give the Indian judiciary this strength are of utmost importance. The moment judicial accountability wavers it creates a vacuum where, both the political class and vested interests would take advantage of the conundrum to further reduce the credibility of the judiciary whereas, an accountable judicial institution can only lead to a stable political atmosphere as well as a far more efficient system of governance. However, it is also acknowledged that judicial accountability if stretched too far can seriously hamper judicial independence and thus it is essential that we strike the right balance between the two.

Certain situations like the allegations on the CJI may arise question on the integrity of the court of law and also the faith of people in the legal system may hinder, "the combination of absolute power, complete opacity, and no accountability in the office of Chief Justice basically means that for the institution to 
survive, every CJI must be utterly incorruptible, absolute impartial, and beyond reproach." The researcher also believe that based on the US model to improve the undisputedly ineffective mode of impeachment the Lokh Sabha in case of $2 / 3 \mathrm{rd}$ majority should be empowered to impeach the sitting judge there and then, and in case of a $2 / 3 \mathrm{rd}$ majority in the Rajya Sabha the Judge should be convicted for his alleged offence. This will make the process more expeditious and transparent and also make judges think twice before usurping their "Independence" to break the trust of this country's true Sovereign.

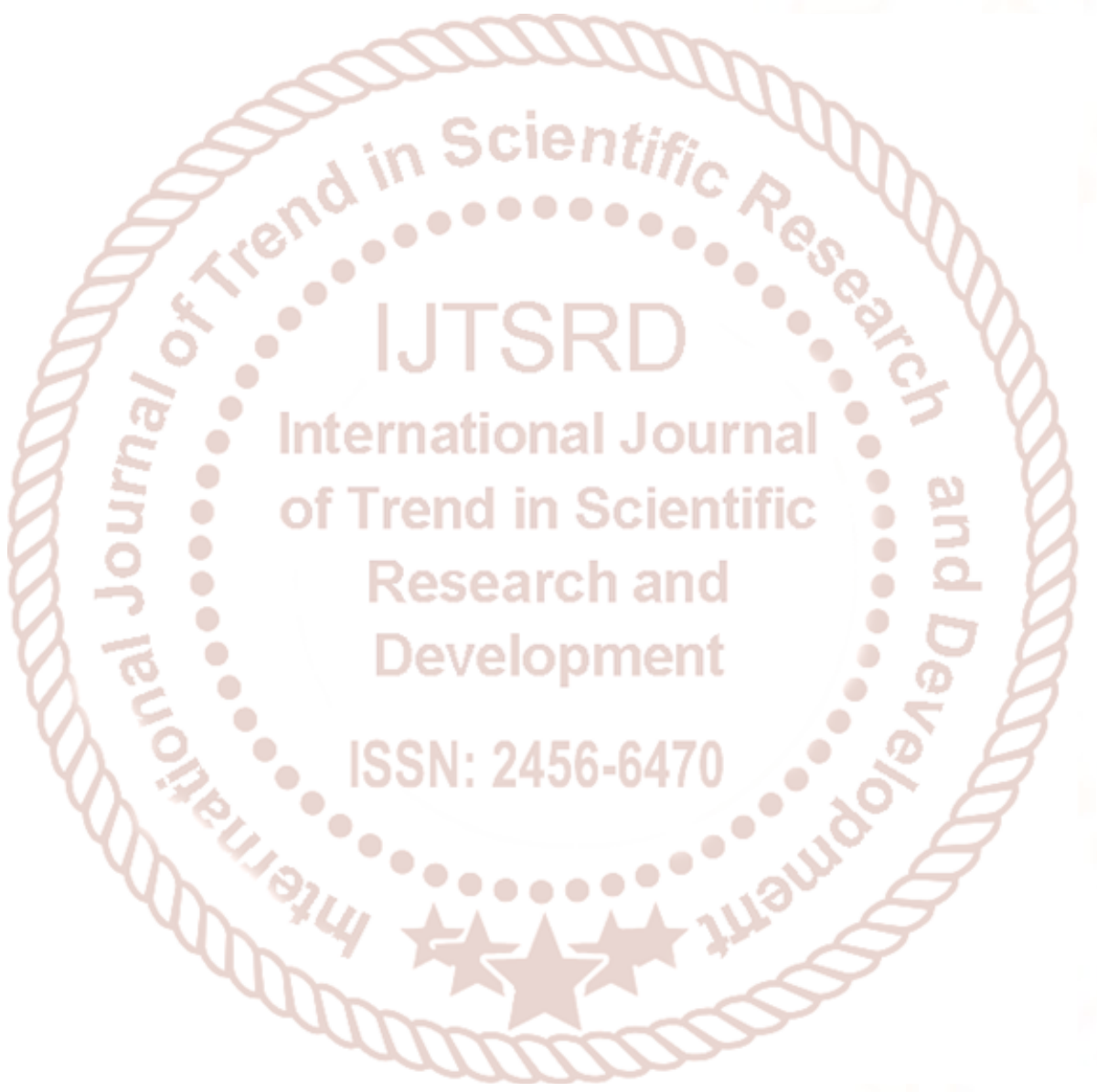

